\title{
Total Selenium and Selenium Species in Irrigation Drain Inflows to the Salton Sea, California, October 2007 and January 2008
}

Open-File Report 2008-1178 



\section{Total Selenium and Selenium Species in Irrigation Drain Inflows to the Salton Sea, California, October 2007 and January 2008}

By Thomas W. May, Michael J. Walther, Michael K. Saiki, and William G. Brumbaugh

Open-File Report 2008-1178 


\section{U.S. Department of the Interior DIRK KEMPTHORNE, Secretary}

\section{U.S. Geological Survey \\ Mark D. Myers, Director}

\section{U.S. Geological Survey, Reston, Virginia: 2008}

For product and ordering information:

World Wide Web: http://www.usgs.gov/pubprod

Telephone: 1-888-ASK-USGS

For more information on the USGS — the Federal source for science about the Earth, its natural and living resources, natural hazards, and the environment:

World Wide Web: http://www.usgs.gov

Telephone: 1-888-ASK-USGS

Any use of trade, product, or firm names is for descriptive purposes only and does not imply endorsement by the U.S. Government.

Although this report is in the public domain, permission must be secured from the individual copyright owners to reproduce any copyrighted materials contained within this report.

Suggested citation:

May, T.W., Walther, M.J., Saiki, M.K., and Brumbaugh, W.G., 2007, Total selenium and selenium species in irrigation drain inflows to the Salton Sea, California, October 2007 and January 2008: U.S. Geological Survey Open-File Report 2008-1178, 14 p. 


\section{Contents}

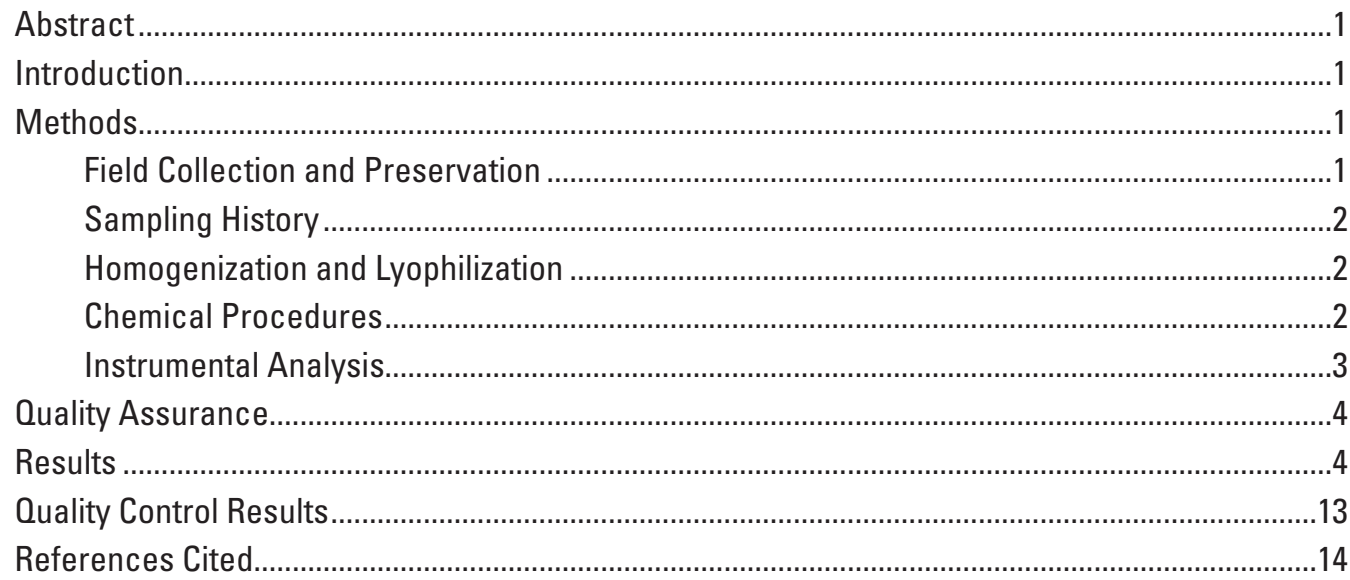

\section{Tables}

1. Total selenium concentrations in duplicates of unfiltered irrigation drain water samples, Salton Sea, California, October 2007

2. Total selenium concentrations in duplicates of unfiltered irrigation drain water samples, Salton Sea, California, January 2008 ...............................................................

3. Total dissolved selenium, dissolved selenium species, and particulate selenium concentrations in filtered irrigation drain water samples, Salton Sea, October 2007 ......7

4. Total suspended solids concentrations in unfiltered Salton Sea irrigation drain water samples, October 2007 and January 2008

5. Selenium concentrations in biota samples collected from Salton Sea irrigation drains, October 2007

6. Selenium concentrations in detritus and sediment samples collected from Salton Sea irrigation drains, October 2007.

7. Particle size distributions in sediment samples collected from Salton Sea irrigation drains, October 2007

8. Percent total organic carbon in sediment samples collected from Salton Sea irrigation drains, October 2007 


\section{Conversion Factors}

\begin{tabular}{lll}
\hline \multicolumn{1}{c}{ Multiply } & By & \multicolumn{1}{c}{ To obtain } \\
\hline & Length & \\
\hline millimeter) & 0.03937 & inch (in.) \\
micrometer $(\mu \mathrm{m})$ & 0.0000393 & inch (in.) \\
\hline & Volume & \\
\hline liter $(\mathrm{L})$ & 33.82 & ounce, fluid (fl. oz) \\
milliliter $(\mathrm{mL})$ & 0.034 & ounce, fluid (fl. oz) \\
\hline & Mass & \\
\hline gram $(\mathrm{g})$ & 0.03527 & ounce, avoirdupois (oz) \\
milligram $(\mathrm{mg})$ & 0.000035 & ounce (oz) \\
\hline
\end{tabular}

Temperature in degrees Celsius $\left({ }^{\circ} \mathrm{C}\right)$ may be converted to degrees Fahrenheit $\left({ }^{\circ} \mathrm{F}\right)$ as follows:

$$
{ }^{\circ} \mathrm{F}=\left(1.8 \times{ }^{\circ} \mathrm{C}\right)+32
$$

Concentrations of chemical constituents in water are given in milligrams per liter (mg/L) or micrograms per liter $(\mu \mathrm{g} / \mathrm{L})$. .

Concentrations of chemical constituents in solid materials are given in micrograms per gram $(\mu \mathrm{g} / \mathrm{g})$. 


\title{
Total Selenium and Selenium Species in Irrigation Drain Inflows to the Salton Sea, California, October 2007 and January 2008
}

\author{
By Thomas W. May, Michael J. Walther, Michael K. Saiki, and William G. Brumbaugh
}

\section{Abstract}

This report presents the results for two sampling periods (October 2007 and January 2008) during a 4-year monitoring program to characterize selenium concentrations in selected irrigation drains flowing into the Salton Sea, California. Total selenium, selenium species (selenite, selenate, organoselenium), and total suspended solids were determined in water samples, and total selenium was determined in sediment, detritus, and biota that included algae, plankton, midge larvae (family, Chironomidae), and two fish species - western mosquitofish ( Gambusia affinis) and sailfin molly (Poecilia latipinna). In addition, sediments were analyzed for percent total organic carbon and particle size. Mean total selenium concentrations in water for both sampling periods ranged from 0.97 to 64.5 micrograms per liter, predominately as selenate, which is typical of waters where selenium is leached out of selenium-containing marine shales and associated soils under alkaline and oxidizing conditions. Total selenium concentrations (micrograms per gram dry weight) ranged as follows: algae, 0.95 to 5.99 ; plankton, 0.15 to 19.3 ; midges, 1.39 to 15.4 ; fish, 3.71 to 25.1 ; detritus, 0.85 to 21.7; sediment, 0.32 to 7.28 .

\section{Introduction}

Monitoring surveys are being conducted by the U.S. Geological Survey (USGS) for 4 years to provide a profile of selenium concentrations in selected irrigation drain inflows to the Salton Sea, California. To accomplish this goal, total selenium, selenium species (selenite, selenate, organoselenium), and total suspended solids were determined in water samples, and total selenium in sediment, detritus, and biota that included algae, plankton, midge larvae (family, Chironomidae), and two fish species-western mosquitofish (Gambusia affinis) and sailfin molly (Poecilia latipinna). In addition, sediments were analyzed for percent total organic carbon and particle size. The results in this report were derived from samples collected during October 2007 and January 2008.

\section{Methods}

\section{Field Collection and Preservation}

The USGS sampling team used the laboratory at the U.S. Fish and Wildlife Service Sonny Bono Salton Sea National Wildlife Refuge (henceforth referred to as "the Refuge" in this report) for certain aspects of sample processing and for preparing samples for shipment during field trips to irrigation drains.

Unfiltered Water: Each total selenium water sample was poured through a 1-millimeter $(\mathrm{mm})$ polypropylene sieve attached to a 1-liter (L) pre-cleaned borosilicate glass bottle. Upon collection, the water sample was acidified to less than $\mathrm{pH} 2$ with 6 normal $(\mathrm{N})$ hydrochloric acid $(\mathrm{HCl})$, chilled to approximately 4 degrees Celsius $\left(\sim 4{ }^{\circ} \mathrm{C}\right)$, and kept in the dark during transport to the USGS. Each water sample intended for analysis of total suspended solids (TSS) was poured through a 1-mm polypropylene sieve attached to a pre-cleaned widemouth 1-L polypropylene bottle. The TSS samples were chilled $\left(\sim 4^{\circ} \mathrm{C}\right)$ during transport to the USGS.

Filtered Water: Water for selenium speciation was filtered using a Geotech ${ }^{\circledR}$ peristaltic pump equipped with a standard pumphead and high-capacity 0.45 micrometer $(\mu \mathrm{m})$ filter capsule certified for trace-element background. All tubing was acid-cleaned silicone; a new length was used at each site and for the blank. At each site, $1 \mathrm{~L}$ of deionized (DI) water was filtered through the filter capsule followed by site water. The first 200 milliliters $(\mathrm{mL})$ of site water eluant were discarded, then $1 \mathrm{~L}$ of eluant was collected in an acid-cleaned 1-L borosilicate glass bottle, acidified, and stored as described earlier for unfiltered water.

Particulates: A polycarbonate Geotech ${ }^{\circledR} 142-\mathrm{mm}$ plate filter apparatus was used with a $142-\mathrm{mm} 0.4-\mu \mathrm{m}$ polycarbonate filter. At each site, $0.5 \mathrm{~L}$ of DI water was filtered through the plate filter, followed by up to $1 \mathrm{~L}$ of site water; after volume notation, the filtrate was discarded. Each filter was placed in a pre-cleaned plastic petri dish $(150 \mathrm{~mm} \times 15 \mathrm{~mm})$ with the particulate side up and sealed with its corresponding cover for freezer storage and transport to the USGS. The plate filtration 
unit was rinsed with 0.1 percent nitric acid $\left(\mathrm{HNO}_{3}\right)$ followed by a DI water rinse after sampling was completed at each site.

Sediment: Five sampling points for sediment collection were identified along the length of each drain. At each sampling point, sediment was collected from 2 to 6 centimeters in depth with a stainless steel dredge. The dredge was cleared of mud and rinsed with site water while used within a drain; at a new site, the dredge was rinsed with DI water followed by site water before the first sample was collected. From each of the five sampling points, enough sediment to fill a $250-\mathrm{mL}$ container was collected and mixed to form a composite sample (1,250-mL total). An aliquot of this composite was then placed into both a 120- and 500-mL polypropylene container for each drain sampled. All containers were placed on ice in the field. Samples were chilled $\left(\sim 4{ }^{\circ} \mathrm{C}\right)$ during transport to the USGS.

Midge larvae and detritus: An insect sweep net was used to collect samples of midge larvae and detritus, which were then sorted and hand-picked with plastic tweezers in a polypropylene sieve, and stored temporarily in a plastic food-storage container on ice. After rinsing with DI water, samples were wrapped in plastic wrap, stored in separate plastic bags, and frozen.

Fish: Composite samples of western mosquitofish and sailfin molly were collected with seine nets and minnow traps; sampled material from each site was stored temporarily in a plastic food-storage container on ice. Upon return to the Refuge lab, the whole-body fish were measured for standard length, weighed, and rinsed with DI water. Each fish composite sample $(n=36)$ was wrapped in plastic wrap and placed into a plastic bag and frozen.

Algae and Plankton: Algae were collected from floating masses or scraped from sticks and rocks at each drain site and stored temporarily in a sealable plastic food-storage container on ice. Following collection, the material was rinsed with DI water, wrapped with plastic wrap, stored in a sealable plastic bag, and frozen. Plankton was collected with a tow net; after draining site water, each sample was rinsed three times with DI water. The plankton and the DI rinsing water were placed in a $120-\mathrm{mL}$ polypropylene container. Collected samples were stored on ice in the field and frozen immediately upon return to the Refuge.

\section{Sampling History}

The irrigation drain monitoring samples that are the subject of this report were received in five shipments and were collected by USGS personnel. Shipments were received by the Environmental Chemistry Branch Inorganic Section (henceforth referred to as "the lab" in this report) of the USGS shortly after collection to meet the 7-day holding time specified for TSS in water and the 14-day holding time for total organic carbon (TOC) in sediments.

The first set of samples was collected during October 11 to 14,2007 , received by the lab on October 16, 2007, and contained 15 TSS water samples, 18 water samples for total selenium, and 6 water samples for total dissolved selenium.
The samples were assigned USGS-CERC batch number 1418 and USGS sample identification numbers 40912 to 40950 .

The second set of samples was collected during October 11 to 16, 2007, received by the lab on October 18, 2007, and contained 16 TSS water samples, 30 total selenium sediment samples, 11 total dissolved selenium water samples, 8 TOC/PSA sediment samples, 8 total selenium sediment samples, and 15 particulate samples. The samples were assigned USGS batch number 1419 and USGS sample identification numbers 40951 to 41038.

The third set of samples was collected during October 13 to 21,2007 , received by the lab on October 31,2007 , and contained 42 fish samples, 21 algae samples, 21 midge samples, 21 detritus samples, and 21 plankton samples. The samples were assigned USGS batch number 1421 and USGS sample identification numbers 41068 to 41193 .

The fourth set of samples was collected during January 10 to 12,2008 , received by the lab on January 15,2008 , and contained 15 TSS water samples and 44 total selenium water samples. The samples were assigned USGS batch number 1434 and USGS sample identification numbers 41569 to 41627.

The fifth set of samples was collected during January 12 to 16,2008 , received by the lab on January 17,2008 , and contained 16 TSS water samples and 18 total selenium water samples. The samples were assigned USGS batch number 1435 and USGS sample identification numbers 41628 to 41661 .

\section{Homogenization and Lyophilization}

Frozen fish samples were minced with a small ceramic knife before freeze drying. Particulates, biota, detritus, and sediment samples were lyophilized in a Virtis Genesis ${ }^{\circledR} 35 \mathrm{EL}$ freeze dryer and percent moisture was determined as part of the lyophilization process; however, percent moisture was not determined for plankton samples because the sample matrix included DI water. After lyophilization, all midge larvae, detritus, plankton, algae, and fish samples were homogenized by grinding with a glass rod against the container surface. Dried sediment was placed into a plastic bag, sealed, and then further reduced in size by using a rolling pin on the plastic bag to produce a coarse powder product. Dried filters containing particulates did not require any additional homogenization after freeze drying.

\section{Chemical Procedures}

Total Selenium in Water: Before analysis, all water samples were stored in the dark at $\sim 4^{\circ} \mathrm{C}$. For the subsequent determination of total selenium in filtered and unfiltered samples, a 20-mL aliquot of each acidified water sample was subjected to an $\mathrm{HNO}_{3}$-magnesium nitrate $\left[\mathrm{Mg}\left(\mathrm{NO}_{3}\right)_{2}\right]$ ashing procedure followed by treatment with $\mathrm{HCl}$. The ashing procedure consisted of three steps: boiling with $\mathrm{HNO}_{3}$ for 
solubilization and partial oxidation, ashing at $500{ }^{\circ} \mathrm{C}$ with $\mathrm{Mg}\left(\mathrm{NO}_{3}\right)_{2}$ to complete the oxidation and decompose remaining organic matter, and heating with $\mathrm{HCl}$ to dissolve the ash and reduce selenium to the selenite $\left(\mathrm{Se}^{+4}\right)$ oxidation state required for detection by hydride generation atomic absorption spectrophotometry. Following reduction, digestates were diluted to $\sim 100 \mathrm{~mL}$ with DI water, yielding a final acid matrix of 10 percent $\mathrm{HCl}$.

Selenite + Selenate in Water: Ten $\mathrm{mL}$ of filtered water and $5 \mathrm{~mL}$ of concentrated $\mathrm{HCl}$ were placed in a $25-\mathrm{mL}$ borosilicate test tube and heated to 125 to $130{ }^{\circ} \mathrm{C}$ in a well incubator block for 3 to 4 hours. After cooling, the liquid was transferred into a $125-\mathrm{mL}$ polyethylene bottle, and the final volume was adjusted to $50 \mathrm{~mL}$ with DI water; the final matrix was 10 percent $\mathrm{HCl}$.

Filtered Particulates: A dried filter containing particulates was rolled up, cut into pieces, and the entire filter was put into a $100-\mathrm{mL}$ glass beaker. The filter was then subjected to the ashing procedure as described earlier for total selenium in water. The same procedure was conducted on clean filters, which served as blanks.

Biota, Detritus, and Sediment: An approximately 0.25gram (g) aliquant of each dried sample was subjected to a $\mathrm{HNO}_{3}-\mathrm{Mg}\left(\mathrm{NO}_{3}\right)_{2}$ ashing procedure followed by $\mathrm{HCl}$ reduction for the determination of selenium. The steps in the procedure were the same as those described above for total selenium in water. Digestates were diluted to about $100 \mathrm{~mL}$ with DI water, yielding a final acid matrix of 10 percent $\mathrm{HCl}$.

\section{Instrumental Analysis}

Total Selenium: Total selenium was determined in all ashed samples by flow injection hydride generation atomic absorption spectrophotometry (FIHGAAS). In this procedure, the digestate is mixed with an $\mathrm{HCl}$-carrier solution, and then reduced by sodium tetrahydridoborate that has been stabilized with sodium hydroxide. Selenium in the sample is converted to volatile hydrogen selenide and transferred with argon carrier gas into a heated quartz cell mounted on an atomic absorption spectrophotometer for decomposition into atomic vapor and measurement.

Selenite in Water: An aliquot of each filtered water sample was analyzed directly by FIHGAAS after acidification to 10 percent $\mathrm{HCl}$.

Selenate and Selenite in Water: As previously described, filtered water samples were subjected to hot $\mathrm{HCl}$ reduction for 3 to 4 hours using a well incubator block. Samples prepared in this manner were analyzed directly by FIHGAAS to provide selenate + selenite concentrations. The selenate concentration was calculated by difference using the formula:

$$
\text { selenate }=(\text { selenate }+ \text { selenite })-\text { selenite } .
$$

Particulate Selenium in Water: Selenium associated with filtered particulates was determined by analyzing ashed filters by FIHGAAS. The mass of selenium in micrograms for the particulates was divided by the volume of water filtered for each drain site $(0.5$ or $1.0 \mathrm{~L})$ to produce a microgram per liter concentration.

Dissolved Organic Selenium in Water: Dissolved organic selenium was estimated using the following formula:

$$
\text { dissolved organic selenium }=\text { total dissolved selenium }-
$$$$
\text { (selenate }+ \text { selenite). }
$$

Total Suspended Solids: Upon arrival at the USGS, all TSS samples were transferred to the Ecology Branch for TSS analysis. Total suspended solids were analyzed with methods recommended by the American Public Health Association (1998). Samples were brought to room temperature and mixed with a magnetic stirrer and subsequent manual inversions of the sample container. The sample was measured into a graduated cylinder, poured into a filtration apparatus, and filtered through a ProWeigh ${ }^{\circledR}$ glass fiber filter. The samples were prewashed three times in DI water, dried at $105^{\circ} \mathrm{C}$, and weighed to the nearest 0.1 milligram (mg). Sample volume varied to yield a dried residue between 2.5 and $200 \mathrm{mg}$. For each volume of sample used, an equal volume of DI water also was filtered for a blank determination. After filtering, large or nonhomogeneous materials were removed from the filter, and the filter was rinsed with three 10-mL aliquots of DI water. Filters were then dried for at least 1 hour in a 103 to $105^{\circ} \mathrm{C}$ oven and cooled to room temperature in a desiccator; filter and residue were weighed to the nearest $0.0001 \mathrm{~g}$. Drying, cooling, and weighing of the filter were repeated until the weight difference was less than (<) 4 percent or $0.5 \mathrm{mg}$, whichever was less. The average of these weights was used to determine the constant weight of the filter and residue, which was then corrected for any weight gain or loss of the blank. After subtracting the filter weight, this blank corrected dried residue in milligrams was divided by the sample volume in liters to yield TSS in milligrams per liter.

Particle-size Analysis: Sediment samples designated for particle size analysis (PSA) were transferred to the USGS Ecology Branch upon arrival. The method requires use of a Bouyoucos hydrometer, adapted from American Society for Testing and Materials (2003). Wet sediment was sieved through a 2-mm sieve to remove any particles larger than coarse sand, and then dried at $60^{\circ} \mathrm{C}$ using a convectional drying oven. Approximately $100 \mathrm{~g}$ of dried sediment was mixed with $250 \mathrm{~mL}$ of DI water and $100 \mathrm{~mL}$ of a $50 \mathrm{mg} / \mathrm{L}$ sodium hexametaphosphate solution. A stir bar was added and the mixture was stirred with a magnetic stirring plate. After calibrating the hydrometer, the suspended sediment mixture was transferred to a sedimentation cylinder and the volume adjusted to $1 \mathrm{~L}$ with DI water. After allowing for thermal equilibration, the temperature was recorded. Cylinder contents were then thoroughly mixed, and the hydrometer was inserted into the suspension. The meniscus reading was taken after 30 seconds and the hydrometer was removed and dried. After 120 minutes, the hydrometer was reinserted and the meniscus 
read again. All hydrometer meniscus readings were corrected by adjusting +0.25 for each degree above $18{ }^{\circ} \mathrm{C}$ and -0.25 for each degree below $18{ }^{\circ} \mathrm{C}$. Percent fractions were determined as follows:

grams sand $=$ sediment dry weight $-($ corrected 30 second reading - corrected calibration);

percent sand $\quad=$ grams sand/sediment dry weight $\times 100$;

grams clay $\quad=$ sediment dry weight $-($ corrected 120 minute reading - corrected calibration);

percent clay $\quad=$ grams clay/sediment dry weight $\times 100$; and

percent silt $\quad=100-($ percent sand + percent clay $)$.

Total Organic Carbon: TOC was determined with a Universal Instruments Corporation (UIC) Model 5014 Coulometer that determines carbon in any carbon dioxide $\left(\mathrm{CO}_{2}\right)$ containing gas stream (Universal Instruments Corporation, 1999). The coulometer is used as a detector with different carbon front-end units and can detect carbon in the range of $0.01 \mathrm{micrograms}(\mu \mathrm{g})$ to $100 \mathrm{mg}$. The coulometer cell is filled with a proprietary solution containing monoethanolamine and a colorimetric $\mathrm{pH}$ indicator. Platinum (cathode) and silver (anode) electrodes are positioned in the cell. The cell assembly is then placed in the coulometer cell compartment between a light source and a photodetector in the coulometer. As a $\mathrm{CO}_{2}$ gas stream passes into the cell, the $\mathrm{CO}_{2}$ is quantitatively absorbed, reacting with the monoethanolamine to form a titratable acid. This acid causes the color indicator to fade. A photodetector monitors the change in the color of the solution as a percent transmittance $(\% \mathrm{~T})$. As the $\% \mathrm{~T}$ increases, the titration current is automatically activated to electrochemically generate base at a rate proportional to the $\% \mathrm{~T}$ (approximately $1,500 \mu \mathrm{g}$ carbon/minute). When the solution returns to its original color (original \% $\mathrm{T}$ ), the current stops.

For TOC analysis, total carbon (TC, $\mu \mathrm{g} / \mathrm{mg}$ ) and total inorganic carbon (TIC, $\mu \mathrm{g} / \mathrm{mg}$ ) are determined. Total carbon is determined by combustion of weighed sediments at $925^{\circ} \mathrm{C}$. In TIC analysis, weighed sediments are exposed to heated 2 Normal sulfuric acid. Any inorganic carbonates are reduced to mineral components and $\mathrm{CO}_{2}$ gas. The gas is carried in high purity oxygen to the coulometer cell, where it is measured by the procedure described above. Percent TOC is calculated as follows:

$$
\text { Percent TOC }=[(\mathrm{TC}-\mathrm{TIC}) / 1000] \times 100
$$

\section{Quality Assurance}

Samples were processed through the preparative and analytical flow scheme in 15 analytical blocks for selenium, 2 blocks for TSS, and 1 block each for PSA and TOC. Each block was assigned a block initiation date (BID) used to identify samples and quality-control samples/materials prepared and analyzed collectively as a unit. For samples analyzed by atomic absorption for total selenium, predigestion quality control included digestion blanks, replicates, spikes, and reference solutions. Analytical quality control for selenium included calibration verification solutions, replicate analyses, and analysis spikes. Quality control for the TSS determination included a reference solution, duplicates, and replicates. Quality control for sediment PSA and TOC included duplicates and replicates.

\section{Results}

Total Selenium: Total selenium concentrations [micrograms per liter, $(\mu \mathrm{g} / \mathrm{L})]$ in unfiltered water samples for the October 2007 samples are listed in table 1. Mean selenium concentrations were most elevated in water from Trifolium Storm drain (20.9) followed by Q drain (8.93). The lowest mean selenium concentration was from Trifolium 19 drain (0.97). Data for the January 2008 samples are listed in table 2. Mean selenium concentrations were highest in Q drain (64.5) followed by Trifolium Storm drain (43.8) and Trifolium 18 drain (32.3). The lowest mean selenium concentration was from $\mathrm{T}$ drain (1.14).

Total Dissolved Selenium and Selenium Species: Dissolved selenite, dissolved selenate, dissolved organic selenium, total dissolved selenium, and particulate selenium concentrations $(\mu \mathrm{g} / \mathrm{L})$ from filtered water samples collected during the October 2007 sampling are presented in table 3. The dissolved organic selenium fraction is assumed to include seleno-amino acids and dissolved seleno- peptides, $\operatorname{Se}(0)$ as a pseudo-dissolved microcolloid, and inorganic Se(-II) species (Cutter and Bruland, 1984). Speciation revealed that selenium in the sampled drains exists predominately as selenate (85 to 95 percent) followed by selenite ( 5 to 15 percent), typical of waters where selenium is leached out of selenium-containing marine shales and associated soils under alkaline and oxidizing conditions.

Total Suspended Solids: TSS concentrations (mg/L) in unfiltered water collected during the October 2007 and January 2008 samplings are presented in table 4 . TSS concentrations ranged from a high of 597 (Trifolium 20 drain) to a low of 8.0 (Former Trifolium 20 drain) for the October 2007 collection, and a high of 780 (W drain) to a low of 6.65 (Former Trifolium 20 drain) for the January 2008 collection.

Biota: Percent moisture and concentrations of selenium (micrograms per gram $(\mu \mathrm{g} / \mathrm{g})$ dry weight) in biota (algae, plankton, midge larvae, western mosquitofish, and sailfin molly) are presented in table 5. Selenium concentration ranges for each matrix were as follows: algae, 0.95 to 5.99; plankton, 0.15 to 19.3 ; midges, 1.39 to 15.4 ; and fish, 3.71 to 25.1 .

Detritus and Sediment: Percent moisture and selenium concentrations ( $\mu \mathrm{g} / \mathrm{g}$ dry weight) in detritus and sediment are presented in table 6 . Selenium in detritus ranged from 0.85 to 21.7 , and from 0.32 to 7.28 in sediment. The particle size analyses of sediments, expressed as percent sand, silt, and 
Table 1. Total selenium concentrations in duplicates of unfiltered irrigation drain water samples, Salton Sea, California, October 2007.

[USGS, U.S. Geological Survey; ID, identification; Rep, field replicate; $\mu \mathrm{g} / \mathrm{L}$, microgram per liter; SD, standard deviation; ---, no data; <, less than; nc, not collected]

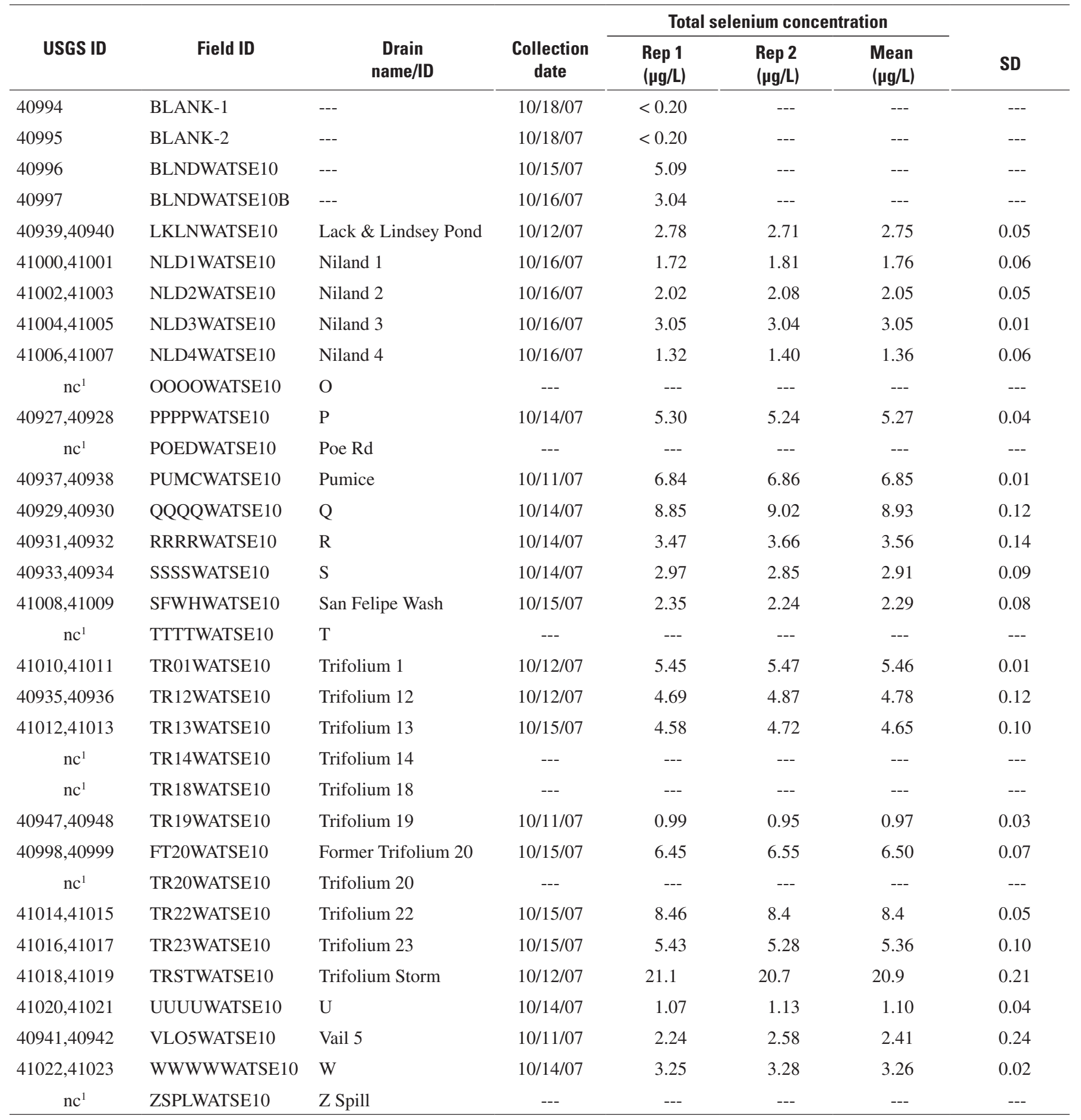

${ }^{1}$ Drain was one of seven selected for intensive sampling (see table 3). 
Table 2. Total selenium concentrations in duplicates of unfiltered irrigation drain water samples, Salton Sea, California, January 2008.

[USGS, U.S. Geological Survey; ID, identification; Rep, field replicate; $\mu \mathrm{g} / \mathrm{L}$, micrograms per liter; SD, standard deviation; <, less than]

\begin{tabular}{|c|c|c|c|c|c|c|c|}
\hline \multirow[b]{2}{*}{ USGS ID } & \multirow[b]{2}{*}{ Field ID } & \multirow[b]{2}{*}{$\begin{array}{c}\text { Drain } \\
\text { name/ID }\end{array}$} & \multirow[b]{2}{*}{$\begin{array}{l}\text { Collection } \\
\text { date }\end{array}$} & \multicolumn{3}{|c|}{ Total selenium concentration } & \multirow[b]{2}{*}{ SD } \\
\hline & & & & $\begin{array}{l}\text { Rep } 1 \\
(\mu g / L)\end{array}$ & $\begin{array}{l}\text { Rep } 2 \\
(\mu \mathrm{g} / \mathrm{L})\end{array}$ & $\begin{array}{l}\text { Mean } \\
(\mu \mathrm{g} / \mathrm{L})\end{array}$ & \\
\hline 41661 & Blank 2 & --- & 01/16/08 & $<0.21$ & --- & --- & --- \\
\hline 41586 & BLNDWATSE11 & --- & 01/10/08 & 6.27 & --- & --- & --- \\
\hline 41600,41601 & LKLNWATSE11 & Lack \& Lindsey Pond & 01/11/08 & 4.17 & 4.24 & 4.20 & 0.04 \\
\hline 41644,41645 & NLD1WATSE11 & Niland 1 & 01/14/08 & 1.62 & 1.74 & 1.68 & 0.09 \\
\hline 41646,41647 & NLD2WATSE11 & Niland 2 & 01/14/08 & 10.2 & 10.3 & 10.2 & 0.10 \\
\hline 41648,41649 & NLD3WATSE11 & Niland 3 & $01 / 14 / 08$ & 2.70 & 2.41 & 2.56 & 0.20 \\
\hline 41622,41623 & POEDWATSE11 & Poe Rd & 01/10/08 & 6.23 & 5.64 & 5.94 & 0.41 \\
\hline 41598,41599 & PUMCWATSE11 & Pumice & $01 / 12 / 08$ & 6.52 & 6.61 & 6.56 & 0.07 \\
\hline 41590,41591 & QQQQWATSE11 & Q & $01 / 12 / 08$ & 64.0 & 65.0 & 64.5 & 0.72 \\
\hline 41592,41593 & RRRRWATSE11 & $\mathrm{R}$ & 01/12/08 & 2.61 & 2.73 & 2.67 & 0.09 \\
\hline 41594,41595 & SSSSWATSE11 & $\mathrm{S}$ & $01 / 12 / 08$ & 1.19 & 1.12 & 1.15 & 0.05 \\
\hline 41610,41611 & SFWHWATSE11 & San Felipe Wash & 01/10/08 & 2.33 & 2.40 & 2.36 & 0.05 \\
\hline 41618,41619 & TTTTWATSE11 & $\mathrm{T}$ & 01/12/08 & 1.21 & 1.08 & 1.14 & 0.09 \\
\hline 41652,41653 & TR01WATSE11 & Trifolium 1 & 01/15/08 & 6.64 & 6.58 & 6.61 & 0.05 \\
\hline 41596,41597 & TR12WATSE11 & Trifolium 12 & 01/11/08 & 9.28 & 9.11 & 9.19 & 0.13 \\
\hline 41626,41627 & TR20WATSE11 & Trifolium 20 & 01/10/08 & 4.71 & 4.86 & 4.78 & 0.10 \\
\hline 41606.41607 & TR22WATSE11 & Trifolium 22 & 01/10/08 & 5.28 & 4.92 & 5.10 & 0.25 \\
\hline 41608,41609 & TR23WATSE11 & Trifolium 23 & 01/10/08 & 2.79 & 2.76 & 2.77 & 0.02 \\
\hline 41658,41659 & TRSTWATSE11 & Trifolium Storm & 01/15/08 & 43.8 & 43.8 & 43.8 & 0.05 \\
\hline 41616,41617 & UUUUWATSE11 & $\mathrm{U}$ & 01/12/08 & 1.37 & 1.44 & 1.40 & 0.05 \\
\hline 41602,41603 & VL05WATSE11 & Vail 5 & $01 / 12 / 08$ & 2.88 & 2.79 & 2.83 & 0.07 \\
\hline 41614,41615 & WWWWWATSE11 & $\mathrm{W}$ & $01 / 12 / 08$ & 3.54 & 3.51 & 3.52 & 0.02 \\
\hline 41612,41613 & ZSPLWATSE11 & Z Spill & $01 / 12 / 08$ & 3.87 & 3.86 & 3.86 & 0.01 \\
\hline
\end{tabular}




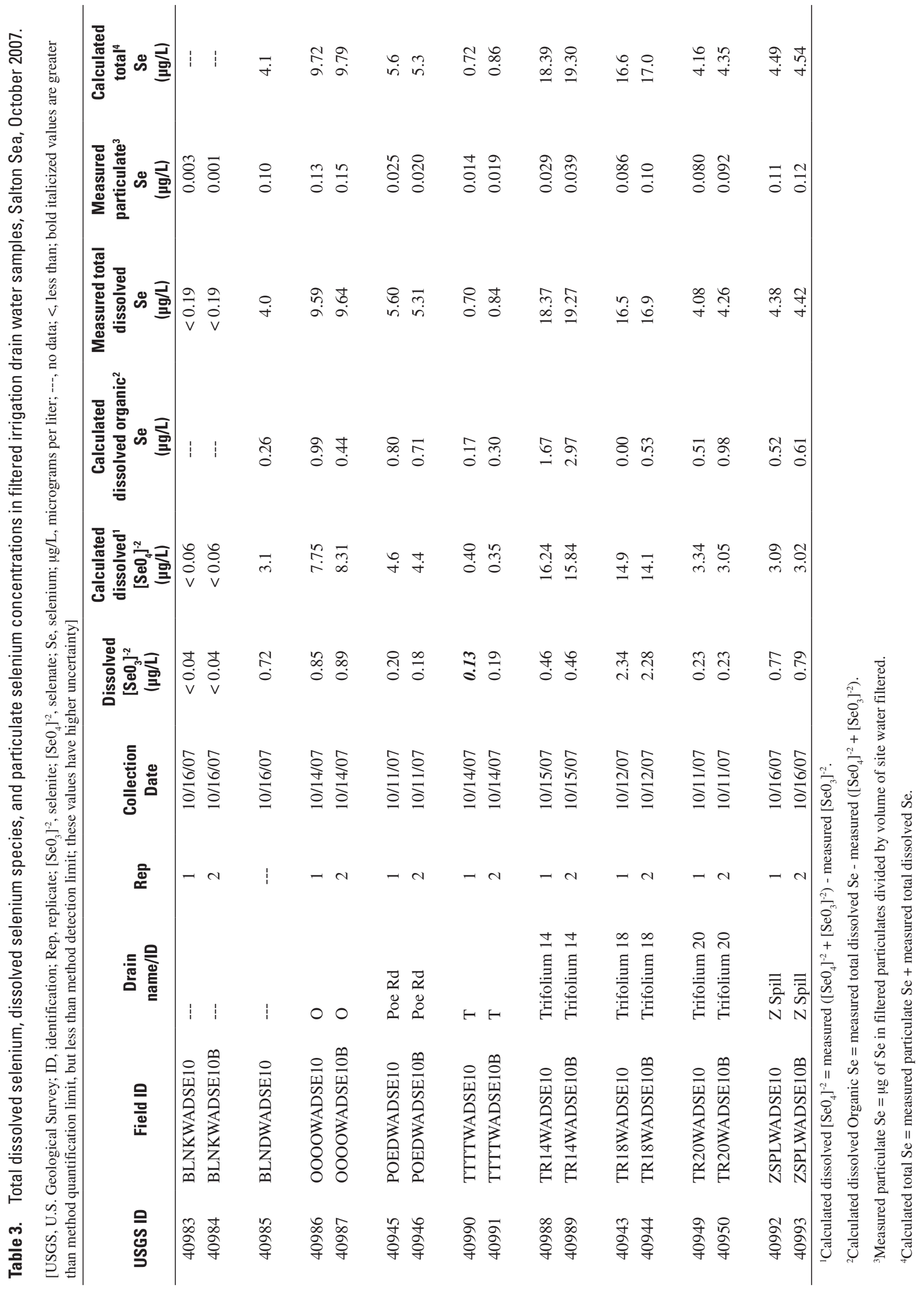


Table 4. Total suspended solids concentrations in unfiltered Salton Sea irrigation drain water samples, 0ctober 2007 and January 2008.

[ID, identification; USGS, U.S. Geological Survey; TSS, total suspended solids; mg/L, milligram per liter]

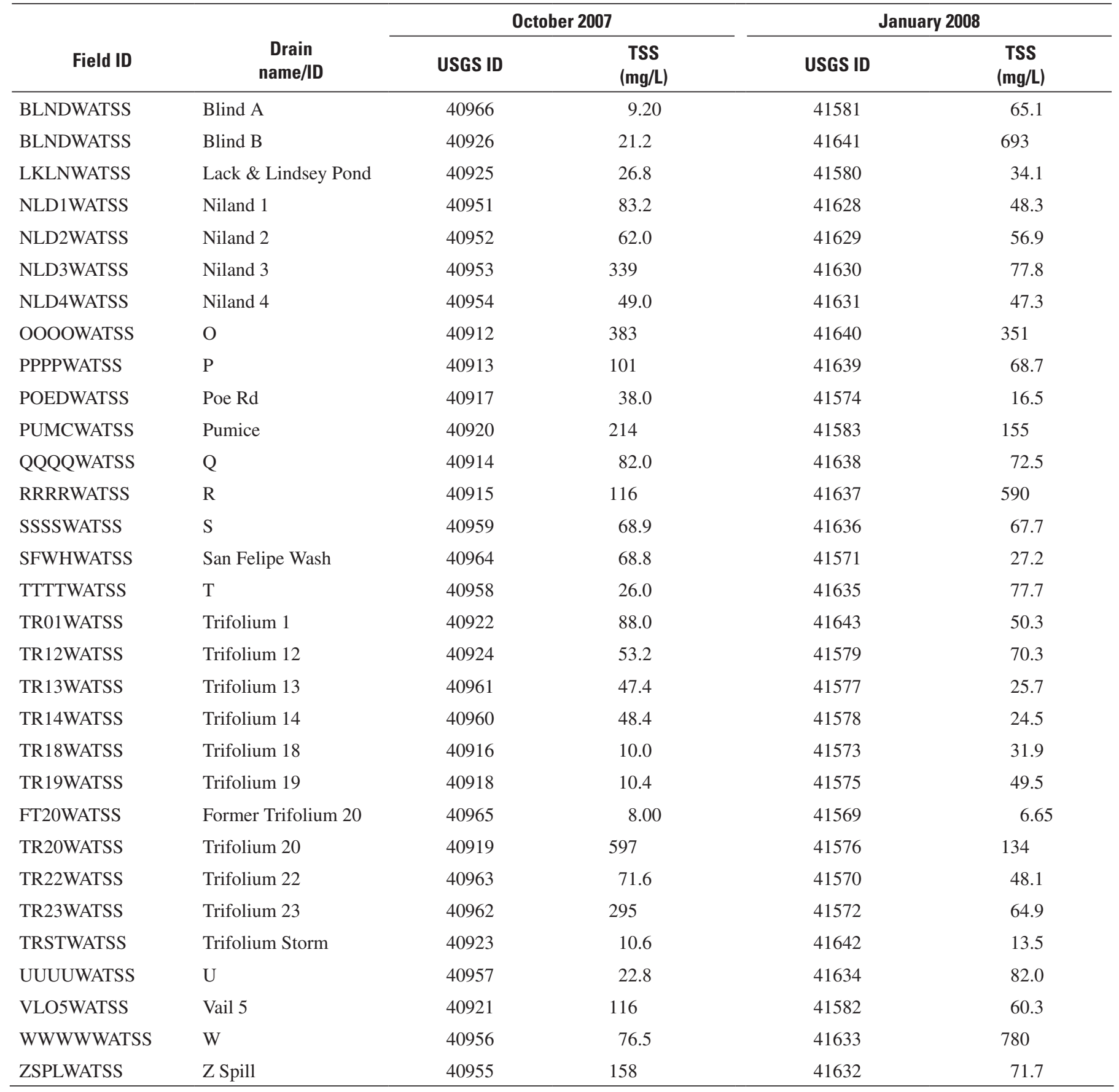


Table 5. Selenium concentrations in biota samples collected from Salton Sea irrigation drains, October 2007.

[USGS, U.S. Geological Survey; ID, identification; $\mu \mathrm{g} / \mathrm{g}$, microgram per gram; ---, no data]

\begin{tabular}{|c|c|c|c|c|c|}
\hline USGS ID & Field ID & Matrix & $\begin{array}{c}\text { Drain } \\
\text { name/ID }\end{array}$ & $\begin{array}{l}\text { Moisture } \\
\text { (percent) }\end{array}$ & $\begin{array}{c}\text { Selenium } \\
\text { ( } \mu \mathrm{g} / \mathrm{g} \text { dry weight) }\end{array}$ \\
\hline 41119 & OOOOALGTSE10A & algae & $\mathrm{O}$ & 56.9 & 3.16 \\
\hline 41120 & OOOOALGTSE10B & algae & $\mathrm{O}$ & 55.1 & 3.22 \\
\hline 41121 & OOOOALGTSE10C & algae & $\mathrm{O}$ & 55.3 & 3.16 \\
\hline 41116 & POEDALGTSE10A & algae & Poe & 54.6 & 1.35 \\
\hline 41117 & POEDALGTSE10B & algae & Poe & 54.7 & 1.32 \\
\hline 41118 & POEDALGTSE10C & algae & Poe & 55.0 & 1.32 \\
\hline 41110 & TTTTALGTSE10A & algae & $\mathrm{T}$ & 65.1 & 0.97 \\
\hline 41111 & TTTTALGTSE10B & algae & $\mathrm{T}$ & 64.8 & 0.96 \\
\hline 41112 & TTTTALGTSE10C & algae & $\mathrm{T}$ & 64.9 & 0.95 \\
\hline 41122 & TR14ALGTSE10A & algae & Trifolium 14 & 66.2 & 3.31 \\
\hline 41123 & TR14ALGTSE10B & algae & Trifolium 14 & 69.4 & 3.28 \\
\hline 41124 & TR14ALGTSE10C & algae & Trifolium 14 & 66.9 & 3.32 \\
\hline 41128 & TR18ALGTSE10A & algae & Trifolium 18 & 63.4 & 5.99 \\
\hline 41129 & TR18ALGTSE10B & algae & Trifolium 18 & 63.3 & 5.73 \\
\hline 41130 & TR18ALGTSE10C & algae & Trifolium 18 & 62.9 & 5.84 \\
\hline 41113 & TR20ALGTSE10A & algae & Trifolium 20 & 60.4 & 2.44 \\
\hline 41114 & TR20ALGTSE10B & algae & Trifolium 20 & 60.5 & 2.47 \\
\hline 41115 & TR20ALGTSE10C & algae & Trifolium 20 & 59.7 & 2.53 \\
\hline 41125 & ZSPLALGTSE10A & algae & Z Spill & 60.0 & 3.88 \\
\hline 41126 & ZSPLALGTSE10B & algae & Z Spill & 61.1 & 3.69 \\
\hline 41127 & ZSPLALGTSE10C & algae & Z Spill & 62.5 & 3.75 \\
\hline 41182 & OOOONPTSE10A & plankton & $\mathrm{O}$ & --- & 2.58 \\
\hline 41183 & OOOONPTSE10B & plankton & $\mathrm{O}$ & --- & 2.90 \\
\hline 41184 & OOOONPTSE10C & plankton & $\mathrm{O}$ & --- & 3.05 \\
\hline 41179 & POEDNPTSE10A & plankton & Poe & --- & 0.21 \\
\hline 41180 & POEDNPTSE10B & plankton & Poe & --- & 0.15 \\
\hline 41181 & POEDNPTSE10C & plankton & Poe & --- & 0.15 \\
\hline 41173 & TTTTNPTSE10A & plankton & $\mathrm{T}$ & --- & 1.05 \\
\hline 41174 & TTTTNPTSE10B & plankton & $\mathrm{T}$ & --- & 0.59 \\
\hline 41175 & TTTTNPTSE10C & plankton & $\mathrm{T}$ & --- & 0.55 \\
\hline 41185 & TR14NPTSE10A & plankton & Trifolium 14 & --- & 4.54 \\
\hline 41186 & TR14NPTSE10B & plankton & Trifolium 14 & --- & 4.04 \\
\hline 41187 & TR14NPTSE10C & plankton & Trifolium 14 & --- & 2.88 \\
\hline 41191 & TR18NPTSE10A & plankton & Trifolium 18 & --- & 12.9 \\
\hline 41192 & TR18NPTSE10B & plankton & Trifolium 18 & --- & 17.9 \\
\hline 41193 & TR18NPTSE10C & plankton & Trifolium 18 & --- & 19.3 \\
\hline 41176 & TR20NPTSE10A & plankton & Trifolium 20 & --- & 1.56 \\
\hline 41177 & TR20NPTSE10B & plankton & Trifolium 20 & --- & 2.23 \\
\hline 41178 & TR20NPTSE10C & plankton & Trifolium 20 & --- & 2.00 \\
\hline
\end{tabular}


Table 5. Selenium concentrations in biota samples collected from Salton Sea irrigation drains, October 2007._-Continued [USGS, U.S. Geological Survey; ID, identification; $\mu \mathrm{g} / \mathrm{g}$, microgram per gram; ---, no data]

\begin{tabular}{|c|c|c|c|c|c|}
\hline USGS ID & Field ID & Matrix & $\begin{array}{c}\text { Drain } \\
\text { name/ID }\end{array}$ & $\begin{array}{l}\text { Moisture } \\
\text { (percent) }\end{array}$ & $\begin{array}{c}\text { Selenium } \\
\text { ( } \mu \mathrm{g} / \mathrm{g} \text { dry weight) }\end{array}$ \\
\hline 41188 & ZSPLNPTSE10A & plankton & Z Spill & --- & 1.47 \\
\hline 41189 & ZSPLNPTSE10B & plankton & Z Spill & --- & 0.84 \\
\hline 41190 & ZSPLNPTSE10C & plankton & Z Spill & --- & 0.39 \\
\hline 41140 & OOOOCHITSE10A & midge & $\mathrm{O}$ & 78.4 & 4.11 \\
\hline 41141 & OOOOCHITSE10B & midge & $\mathrm{O}$ & 76.2 & 3.62 \\
\hline 41142 & OOOOCHITSE10C & midge & $\mathrm{O}$ & 79.7 & 4.26 \\
\hline 41137 & POEDCHITSE10A & midge & Poe & 69.8 & 3.92 \\
\hline 41138 & POEDCHITSE10B & midge & Poe & 76.0 & 5.45 \\
\hline 41139 & POEDCHITSE10C & midge & Poe & 68.4 & 3.01 \\
\hline 41131 & TTTTCHITSE10A & midge & $\mathrm{T}$ & 78.5 & 5.89 \\
\hline 41132 & TTTTCHITSE10B & midge & $\mathrm{T}$ & 78.8 & 6.02 \\
\hline 41133 & TTTTCHITSE10C & midge & $\mathrm{T}$ & 79.9 & 6.49 \\
\hline 41143 & TR14CHITSE10A & midge & Trifolium 14 & 79.9 & 5.40 \\
\hline 41144 & TR14CHITSE10B & midge & Trifolium 14 & 80.1 & 5.40 \\
\hline 41145 & TR14CHITSE10C & midge & Trifolium 14 & 80.2 & 5.31 \\
\hline 41149 & TR18CHITSE10A & midge & Trifolium 18 & 79.2 & 15.4 \\
\hline 41150 & TR18CHITSE10B & midge & Trifolium 18 & 76.1 & 12.8 \\
\hline 41151 & TR18CHITSE10C & midge & Trifolium 18 & 79.6 & 14.5 \\
\hline 41134 & TR20CHITSE10A & midge & Trifolium 20 & 74.9 & 2.21 \\
\hline 41135 & TR20CHITSE10B & midge & Trifolium 20 & 74.8 & 1.95 \\
\hline 41136 & TR20CHITSE10C & midge & Trifolium 20 & 73.8 & 1.39 \\
\hline 41146 & ZSPLCHITSE10A & midge & Z Spill & 78.1 & 2.58 \\
\hline 41147 & ZSPLCHITSE10B & midge & Z Spill & 77.2 & 2.62 \\
\hline 41148 & ZSPLCHITSE10C & midge & Z Spill & 77.9 & 2.30 \\
\hline 41086 & OOOOGMBTSE10A & mosquitofish & $\mathrm{O}$ & 77.1 & 4.43 \\
\hline 41087 & OOOOGMBTSE10B & mosquitofish & $\mathrm{O}$ & 77.5 & 4.76 \\
\hline 41088 & OOOOGMBTSE10C & mosquitofish & $\mathrm{O}$ & 77.9 & 4.20 \\
\hline 41089 & OOOOSLMTSE10A & sailfin molly & $\mathrm{O}$ & 75.3 & 4.21 \\
\hline 41090 & OOOOSLMTSE10B & sailfin molly & $\mathrm{O}$ & 75.9 & 3.71 \\
\hline 41091 & OOOOSLMTSE10C & sailfin molly & $\mathrm{O}$ & 76.2 & 4.50 \\
\hline 41080 & POEDGMBTSE10A & mosquitofish & Poe & 77.3 & 5.89 \\
\hline 41081 & POEDGMBTSE10B & mosquitofish & Poe & 77.3 & 5.97 \\
\hline 41082 & POEDGMBTSE10C & mosquitofish & Poe & 77.9 & 5.44 \\
\hline 41083 & POEDSLMTSE10A & sailfin molly & Poe & 76.7 & 4.65 \\
\hline 41084 & POEDSLMTSE10B & sailfin molly & Poe & 76.2 & 5.27 \\
\hline 41085 & POEDSLMTSE10C & sailfin molly & Poe & 76.7 & 4.68 \\
\hline 41068 & TTTTGMBTSE10A & mosquitofish & $\mathrm{T}$ & 77.3 & 4.09 \\
\hline 41069 & TTTTGMBTSE10B & mosquitofish & $\mathrm{T}$ & 78.4 & 3.72 \\
\hline 41070 & TTTTGMBTSE10C & mosquitofish & $\mathrm{T}$ & 78.7 & 3.94 \\
\hline
\end{tabular}


Table 5. Selenium concentrations in biota samples collected from Salton Sea irrigation drains, October 2007.-Continued

[USGS, U.S. Geological Survey; ID, identification; $\mu \mathrm{g} / \mathrm{g}$, microgram per gram; ---, no data]

\begin{tabular}{|c|c|c|c|c|c|}
\hline USGS ID & Field ID & Matrix & $\begin{array}{c}\text { Drain } \\
\text { name/ID }\end{array}$ & $\begin{array}{l}\text { Moisture } \\
\text { (percent) }\end{array}$ & $\begin{array}{c}\text { Selenium } \\
\text { ( } \mu \mathrm{g} / \mathrm{g} \text { dry weight) }\end{array}$ \\
\hline 41071 & TTTTSLMTSE10A & sailfin molly & $\mathrm{T}$ & 75.9 & 4.38 \\
\hline 41072 & TTTTSLMTSE10B & sailfin molly & $\mathrm{T}$ & 77.2 & 4.36 \\
\hline 41073 & TTTTSLMTSE10C & sailfin molly & $\mathrm{T}$ & 77.4 & 4.92 \\
\hline 41092 & TR14GMBTSE10A & mosquitofish & Trifolium 14 & 76.5 & 5.68 \\
\hline 41093 & TR14GMBTSE10B & mosquitofish & Trifolium 14 & 77.8 & 6.03 \\
\hline 41094 & TR14GMBTSE10C & mosquitofish & Trifolium 14 & 78.1 & 5.78 \\
\hline 41095 & TR14SLMTSE10A & sailfin molly & Trifolium 14 & 73.3 & 4.41 \\
\hline 41096 & TR14SLMTSE10B & sailfin molly & Trifolium 14 & 73.0 & 3.97 \\
\hline 41097 & TR14SLMTSE10C & sailfin molly & Trifolium 14 & 73.4 & 4.58 \\
\hline 41104 & TR18GMBTSE10A & mosquitofish & Trifolium 18 & 78.3 & 14.7 \\
\hline 41105 & TR18GMBTSE10B & mosquitofish & Trifolium 18 & 78.1 & 14.5 \\
\hline 41106 & TR18GMBTSE10C & mosquitofish & Trifolium 18 & 77.2 & 13.2 \\
\hline 41107 & TR18SLMTSE10A & sailfin molly & Trifolium 18 & 78.2 & 25.1 \\
\hline 41108 & TR18SLMTSE10B & sailfin molly & Trifolium 18 & 77.6 & 24.0 \\
\hline 41109 & TR18SLMTSE10C & sailfin molly & Trifolium 18 & 76.9 & 24.3 \\
\hline 41074 & TR20GMBTSE10A & mosquitofish & Trifolium 20 & 80.8 & 4.98 \\
\hline 41075 & TR20GMBTSE10B & mosquitofish & Trifolium 20 & 80.4 & 5.22 \\
\hline 41076 & TR20GMBTSE10C & mosquitofish & Trifolium 20 & 81.3 & 5.01 \\
\hline 41077 & TR20SLMTSE10A & sailfin molly & Trifolium 20 & 78.1 & 4.62 \\
\hline 41078 & TR20SLMTSE10B & sailfin molly & Trifolium 20 & 77.9 & 4.65 \\
\hline 41079 & TR20SLMTSE10C & sailfin molly & Trifolium 20 & 78.2 & 4.79 \\
\hline 41098 & ZSPLGMBTSE10A & mosquitofish & Z Spill & 76.8 & 5.49 \\
\hline 41099 & ZSPLGMBTSE10B & mosquitofish & Z Spill & 76.8 & 6.00 \\
\hline 41100 & ZSPLGMBTSE10C & mosquitofish & Z Spill & 76.3 & 5.81 \\
\hline 41101 & ZSPLSLMTSE10A & sailfin molly & Z Spill & 74.8 & 4.67 \\
\hline 41102 & ZSPLSLMTSE10B & sailfin molly & Z Spill & 76.3 & 4.16 \\
\hline 41103 & ZSPLSLMTSE10C & sailfin molly & Z Spill & 76.7 & 4.85 \\
\hline
\end{tabular}


Table 6. Selenium concentrations in detritus and sediment samples collected from Salton Sea irrigation drains, October 2007.

[USGS, U.S. Geological Survey; ID, identification; $\mu \mathrm{g} / \mathrm{g}$, micrograms per gram]

\begin{tabular}{|c|c|c|c|c|c|}
\hline USGS ID & Field ID & Matrix & $\begin{array}{c}\text { Drain } \\
\text { name/ID }\end{array}$ & $\begin{array}{l}\text { Moisture } \\
\text { (percent) }\end{array}$ & $\begin{array}{c}\text { Selenium } \\
\text { ( } \mu \mathrm{g} / \mathrm{g} \text { dry weight) }\end{array}$ \\
\hline 41161 & OOOODETTSE10A & detritus & $\mathrm{O}$ & 73.5 & 4.75 \\
\hline 41162 & OOOODETTSE10B & detritus & $\mathrm{O}$ & 75.8 & 4.37 \\
\hline 41163 & OOOODETTSE10C & detritus & $\mathrm{O}$ & 75.2 & 2.54 \\
\hline 41158 & POEDDETTSE10A & detritus & Poe & 80.3 & 2.44 \\
\hline 41159 & POEDDETTSE10B & detritus & Poe & 84.4 & 6.55 \\
\hline 41160 & POEDDETTSE10C & detritus & Poe & 81.0 & 3.74 \\
\hline 41152 & TTTTDETTSE10A & detritus & $\mathrm{T}$ & 77.2 & 1.48 \\
\hline 41153 & TTTTDETTSE10B & detritus & $\mathrm{T}$ & 71.5 & 1.30 \\
\hline 41154 & TTTTDETTSE10C & detritus & $\mathrm{T}$ & 73.3 & 0.85 \\
\hline 41164 & TR14DETTSE10A & detritus & Trifolium 14 & 70.9 & 4.39 \\
\hline 41165 & TR14DETTSE10B & detritus & Trifolium 14 & 78.6 & 5.72 \\
\hline 41166 & TR14DETTSE10C & detritus & Trifolium 14 & 76.7 & 3.79 \\
\hline 41170 & TR18DETTSE10A & detritus & Trifolium 18 & 80.0 & 16.4 \\
\hline 41171 & TR18DETTSE10B & detritus & Trifolium 18 & 81.4 & 13.3 \\
\hline 41172 & TR18DETTSE10C & detritus & Trifolium 18 & 80.8 & 21.7 \\
\hline 41155 & TR20DETTSE10A & detritus & Trifolium 20 & 78.1 & 2.61 \\
\hline 41156 & TR20DETTSE10B & detritus & Trifolium 20 & 75.8 & 1.76 \\
\hline 41157 & TR20DETTSE10C & detritus & Trifolium 20 & 75.7 & 2.35 \\
\hline 41167 & ZSPLDETTSE10A & detritus & Z Spill & 72.3 & 3.59 \\
\hline 41168 & ZSPLDETTSE10B & detritus & Z Spill & 75.3 & 3.37 \\
\hline 41169 & ZSPLDETTSE10C & detritus & Z Spill & 76.4 & 3.62 \\
\hline 40982 & BLNDSDTSE10 & sediment & Blind & 23.0 & 0.32 \\
\hline 40979 & OOOOSDTSE10 & sediment & $\mathrm{O}$ & 48.6 & 0.97 \\
\hline 40976 & POEDSDTSE10 & sediment & Poe & 23.6 & 0.33 \\
\hline 40980 & TTTTSDTSE10 & sediment & $\mathrm{T}$ & 40.0 & 0.47 \\
\hline 40978 & TR14SDTSE10 & sediment & Trifolium 14 & 56.0 & 2.40 \\
\hline 40977 & TR18SDTSE10 & sediment & Trifolium 18 & 59.3 & 7.28 \\
\hline 40975 & TR20SDTSE10 & sediment & Trifolium 20 & 52.2 & 1.39 \\
\hline 40981 & ZSPLSDTSE10 & sediment & Z Spill & 55.9 & 1.44 \\
\hline
\end{tabular}


clay, are presented in table 7. Percent sand ranged from 19.6 to 64.5; percent silt from 17.8 to 53.3 ; and percent clay from 8.98 to 41.6. Percent TOC in sediments is given in table 8 and ranged from 0.03 to 1.73 .

\section{Quality Control Results}

Calibration Verification: During the selenium determinations, a calibration verification solution (Spex Claritas PPT ${ }^{\circledR}$; Cat No. CLSe2-2Y) was analyzed at the beginning and end of each analytical run. Calibration was considered acceptable if the check solution was within plus or minus 10 percent of the actual concentration $(3 \mu \mathrm{g} / \mathrm{L})$, which was achieved during all analyses.

Reference Materials: Recoveries of selenium from QC Plus + Trace Metals Quality Control Standard [n=8 (8 samples)] and National Institute of Standards and Technology
(NIST) Standard Reference Material (SRM) 1640 Trace Elements in Natural Water $(n=8)$ averaged 99 percent. Recoveries of selenium from NIST SRM 2704 Buffalo River sediment $(\mathrm{n}=1)$ and National Research Council Canada (NRCC) SRM PACS-1 marine sediment $(n=1)$ were 100 percent. The International Atomic Energy Agency (IAEA) copepod reference material MA-A-1 $(n=3)$ and the Institute for Reference Materials and Measurements Certified Reference Material (CRM) 414 Trace Elements in Plankton (n=3) all exhibited selenium recoveries of 100 percent. Recoveries of selenium in NRCC CRM DORM-2 dogfish muscle $(n=2)$ and IAEA CRM 407 whole-body fish $(n=2)$ averaged 100 and 97 percent. Recoveries of TSS from a TSS reference solution (Environmental Resource Associates Hardness Wastewater Standard 507; n=4) were 100 percent. The recovery of total carbon from a carbon reference material (Environmental Resource Associates Nutrients in Soil 542; $\mathrm{n}=1$ ) was 100 percent.

Table 7. Particle size distributions in sediment samples collected from Salton Sea irrigation drains, October 2007.

[USGS, U.S. Geological Survey; ID, identification; >, greater than; mm, millimeter]

\begin{tabular}{|c|c|c|c|c|c|c|}
\hline \multirow[b]{2}{*}{ USGS ID } & \multirow[b]{2}{*}{ Field ID } & \multirow{2}{*}{$\begin{array}{c}\text { Drain } \\
\text { name/ID }\end{array}$} & \multicolumn{4}{|c|}{ Particle size category } \\
\hline & & & $\begin{array}{c}>2 \mathrm{~mm} \\
\text { (percent) }\end{array}$ & $\begin{array}{c}\text { Sand } \\
\text { (percent) }\end{array}$ & $\begin{array}{c}\text { Silt } \\
\text { (percent) }\end{array}$ & $\begin{array}{c}\text { Clay } \\
\text { (percent) }\end{array}$ \\
\hline 40974 & BLNDSDTOC10 & Blind & 0.22 & 63.8 & 18.6 & 17.4 \\
\hline 40971 & OOOOSDTOC10 & $\mathrm{O}$ & 0.64 & 20.8 & 36.9 & 41.6 \\
\hline 40968 & POEDSDTOC10 & Poe Rd & 0.17 & 64.5 & 17.8 & 17.5 \\
\hline 40972 & TTTTSDTOC10 & $\mathrm{T}$ & 0.50 & 34.7 & 33.6 & 31.3 \\
\hline 40970 & TR14SDTOC10 & Trifolium 14 & 0.74 & 20.6 & 53.3 & 25.3 \\
\hline 40969 & TR18SDTOC10 & Trifolium 18 & 0.13 & 60.7 & 30.2 & 8.98 \\
\hline 40967 & TR20SDTOC10 & Trifolium 20 & 0.16 & 26.3 & 36.9 & 36.6 \\
\hline 40973 & ZSPLSDTOC10 & Z Spill & 0.58 & 19.6 & 44.4 & 35.4 \\
\hline
\end{tabular}

Table 8. Percent total organic carbon in sediment samples collected from Salton Sea irrigation drains, 0 ctober 2007.

[USGS, U.S. Geological Survey; ID, identification]

\begin{tabular}{cllr}
\hline USGS ID & Field ID & \multicolumn{1}{c}{$\begin{array}{c}\text { Drain } \\
\text { name/ID }\end{array}$} & $\begin{array}{c}\text { Total organic carbon } \\
\text { (percent) }\end{array}$ \\
\hline 40971 & BLNDSDTOC10 & Blind & 0.66 \\
40968 & OOOOSDTOC10 & O & 0.03 \\
40972 & POEDSDTOC10 & Poe & 0.45 \\
40970 & TTTTSDTOC10 & T & 1.00 \\
40969 & TR14SDTOC10 & Trifolium 14 & 1.73 \\
40967 & TR18SDTOC10 & Trifolium 18 & 1.00 \\
40973 & TR20SDTOC10 & Trifolium 20 & 0.64 \\
40974 & ZSPLSDTOC10 & Z Spill & 0.16 \\
\hline
\end{tabular}


Analytical and Method Precision: Instrumental precision for selenium as determined by repeated analysis of a standard throughout the run for each block $(n=15)$ was less than 5 percent relative standard deviation (RSD). Relative percent differences (RPDs) between field duplicates $(n=72)$ of unfiltered and filtered water samples analyzed for selenium or selenium species mostly were $\leq$ (less than or equal) $10(n=65)$, but 7 duplicates exhibited greater RPDs of 11,12 , $14,18,25$, and 33 attributed to low selenium concentrations $(0.13$ to $3.6 \mu \mathrm{g} / \mathrm{L})$. Field duplicates of selenium in filtered particulates produced RPDs ranging from 8.8 to 31 RPD, with the elevated RPDs again attributed to low selenium concentrations ( 0.014 to $0.15 \mu \mathrm{g} / \mathrm{L})$. Relative standard deviations (RSDs) for triplicate field samples of detritus $(n=7)$, algae $(n=7)$, plankton $(n=7)$, midge larvae $(n=7)$, and whole-body fish $(n=14)$ analyzed for selenium were as follows: algae, 0.6 to 2.6 percent; plankton, 8.5 to 60 percent; detritus, 3.8 to 50 percent; midge larvae, 1.0 to 30 percent; and wholebody fish, 1.9 to 10 percent. The larger RSDs for some of the matrices resulted in some cases from the low selenium concentrations involved to other cases that reflected more the natural variation of selenium in the sample (i.e., detritus and plankton). Laboratory method precision for triplicate $(n=17)$ preparation and analysis of samples for selenium were $<3$ percent RSD. Method duplicates of the various matrices produced RPDs as follows: detritus, 0.1 percent; water, 2.4 and 7.6 percent; sediment $(n=8), 0.4$ to 8.5 percent. Method replicates of the various matrices produced percent RSDs as follows: particulate selenium, 1.6; plankton, 1.3; algae, 0.6; sediment, 3.5; water $(n=10), 0.5$ to 9.4 ; midge larvae, 5.3 and 7.0; fish $(n=3), 2.5$ to 3.2. Duplicate analysis of water samples for TSS $(n=6)$ resulted in RPDs ranging from 0.4 to 7.3 percent, whereas triplicate analysis for TSS $(n=4)$ resulted in RSDs $<5$ percent. Triplicate analyses of a sediment and a sediment control material for PSA resulted in RSDs $<7$ percent for the fractions. The duplicate analysis of a sediment for TOC resulted in an RPD of 3.4 percent.

Spikes: Recoveries of selenium $\left[\mathrm{Se}^{+4}\right.$, selenate $\left(\mathrm{Se}^{+6}\right)$, or selenomethionine] spiked into filter blanks $(n=2)$ and water samples $(n=26)$ ranged from 93 to 109 percent and averaged 99 percent. Recoveries of selenium spiked into sediment $(n=2)$, detritus $(n=1)$, and biota $(n=14)$ ranged from 94 to 108 percent, and averaged 100 percent. Recoveries of selenium spikes added to water during analysis $(n=18)$ ranged from 97 to 108 percent, and averaged 104 percent; analysis spikes of sediment $(n=2)$, filtered particulates $(n=2)$, detritus $(n=2)$, and biota $(n=11)$ ranged from 95 to 108 percent, and averaged 102 percent.

Blank Equivalent Concentrations: Blank equivalent concentrations (BECs) were computed for selenium for each matrix and for TSS blanks analyzed with each set of drain water samples. All BECs were less than or equal to their respective method detection limits (MDLs) with the exception of plankton, where the BEC was about twice the MDL $(0.013 \mu \mathrm{g} / \mathrm{g}$ compared to $0.006 \mu \mathrm{g} / \mathrm{g})$. BECs for TSS were less than or equal to their respective MDLs. TSS sample data were corrected for procedural blanks, whereas total selenium sample data were not blank corrected.

Instrument Detection, Method Detection, and Method Quantitation Limits: The FIHGAAS instrument detection limit for selenium was $0.02 \mu \mathrm{g} / \mathrm{L}$, and for TSS was 0.10 and $0.12 \mathrm{mg} / \mathrm{L}$. Method detection limits (MDL) for each matrix for selenium were computed for each analytical block $(n=15)$ using the formula:

$$
3\left(\mathrm{SD}_{\mathrm{b}}^{2}+\mathrm{SD}_{\mathrm{s}}^{2}\right)^{1 / 2}
$$

where

$\mathrm{SD}_{\mathrm{b}} \quad$ is standard deviation of a blank $(\mathrm{n}=3)$; and

$\mathrm{SD}_{\mathrm{s}} \quad$ is standard deviation of a low level sample or spiked sample $(n=3)$.

The results were water, 0.043 to $0.21 \mu \mathrm{g} / \mathrm{L}$; filtered particulates, $0.001 \mu \mathrm{g} / \mathrm{L}$; sediment, 0.011 and $0.012 \mu \mathrm{g} / \mathrm{g}$ dry weight; algae, $0.029 \mu \mathrm{g} / \mathrm{g}$ dry weight; midge larvae, $0.017 \mu \mathrm{g} / \mathrm{g}$ dry weight; plankton, $0.006 \mu \mathrm{g} / \mathrm{g}$ dry weight; detritus, $0.029 \mu \mathrm{g} / \mathrm{g}$ dry weight; and whole-body fish, 0.005 and $0.012 \mu \mathrm{g} / \mathrm{g}$ dry weight. Method quantitation limits (MQLs) for each matrix were calculated as $3.3 \mathrm{x}$ MDLs. Method detection limits for TSS were 3.6 and $2.4 \mathrm{mg} / \mathrm{L}$ and MQLs were 11.7 and $7.9 \mathrm{mg} / \mathrm{L}$. Overall, quality control results for the study were within acceptable limits as specified by USGS.

\section{References Cited}

American Public Health Association, 1998, Standard methods for the examination of water and wastewater (20th ed.), Method 2540: Washington, D.C., American Public Health Association, p. 257-258.

American Society for Testing and Materials, 2003, Standard test method for particle-size analysis of soils, D422-63 (2002), in Annual Book of ASTM Standards, v. 04.08: West Conshohocken, Pa., American Society for Testing and Materials, p. 10-17.

Cutter, G.A., and Bruland, K.W., 1984, The marine biogeochemistry of selenium - a re-evaluation: Limnology and Oceanography, v. 29, no. 6, p. 1,179-1,192.

Universal Instruments Corporation, 1999, Operating manual for Model CM 5014 Coulometer. 
Publishing support provided by: Rolla Publishing Service Center

For more information concerning this publication, contact: Director, USGS Columbia Environmental Research Center 4200 New Haven Road

Columbia, M0 65201

(573) 875-5399

Or visit the Columbia Environmental Reserch Center Web site at: http://www.cerc.usgs.gov 


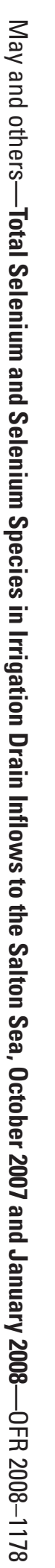

8 Printed on recycled paper 